\title{
「造園家（ランドスケープ・アーキテクト）に期待する」 特集にあたって
}

\section{特集企画担当編集委員 小林 章 恒川 篤史 渡辺 達三 渡辺 綱男}

造園家（ランドスケープ・アーキテクト）の活動領域 は近年ますます拡大し, 広範多岐にわたっている。その ため, 造園家像が絞りにくくなったように感じられる。 技術者集団として見た場合, 造園家は相变わらず少数派 であることに変わりはないが, 活動領域の拡大とともに 建築・土木をはじめ，さまざまな分野の人々と共に仕事 をする，業際・学際的な場面む増えている。こうした状 況のなかで造園家のアイデンティティとはいったい何で あろうか。本特集では,「造園家とはいかなる存在であ るのか」という本質的な問題を考え直してみたい。造園 （ランドスケープ）に対する社会的要請がますます高ま る一方, 環境創造に関する仕事がさまざまな分野からア プローチされている。造園家が他分野の人々と共同して 仕事をする機会が增大している今, 他分野の方々に, そ れぞれの分野からみた造園家像および造園分野への将来 に向けての要望などについてコメントしていただくこと にした。歯がゆい点などを手厳しく指摘していただき， 造園界への刺激になることを期待したいと考えた。

そして本特集では, 自治体首長, 彫刻, 花芸, 建築, 土木, 都市計画, アーバンデザイン, シビックデザイン, 色彩，自然環境の各分野から16氏に執筆をお願いした。

建築家の㴰光夫氏は，現代の日本では，身のまわりに 「秩序」を実感できるような空間が皆無に近いとの認識 のもと, 美しい風景をつくり出していくことへの期待を, 彫刻家の真道茂氏は, 造園は大地の厚肉のレリーフのよ うに思えるとされ，造形のトレーニングや，造園にたず さわる様々な人達が同時に問題をかかえることの重要性 を、花芸家の安達曈子氏は、ご自身の体験をもとに住ま いの庭園や周辺の環境が人に与える影響の強さを示され， より明確な緑のフィロソフィーの確立への期待を，（株） オズカラースタジオの尾崎真理氏は, 美しい街なみ, 景 観を取り尽すために, 調和を構成する色彩について, 日 本の風土に合う色彩を見つけだすことの重要性を述べら れた。

建築家, 日本大学の宮脇檀氏は, 日本の造園家は植栽 の専門家にとどまる人が大部分のように見えたとする経 験と, 地域や風土のグランドデザインへの期待を, アー バンデザイナーの木下正夫氏は, アーバンデザイナーの 一員としての造園家のあるべき姿, 余白と空間, 建築・ ランドスケープと空間について作品批評を通じて論述さ れ,（有）伊東孝都市環境研究室, 法政大学の伊東孝氏
は、土木・都市計画分野の四つの視点（造園の基本、デ ザイン, 住民参加, 歴史の継承性) から要望を述べられた。

神戸市長の笹山幸俊氏は，同市の「アーバンリゾート 都市」構想を紹介され, それと造園家との関わり, 構想 の実現に向けた造園家への期待を述べられ, さらに造園 家への提言を, 大阪大学の鳴海邦碩氏は, 造園家の屯ち うる大地に関するセンス, 都市開発におけるコーディネ イターとしての役割に期待され，オープンスペースの制 度的な体系の整っていない状況についても述べられた。

神奈川県都市部の越沢明氏は造園界之造園家の課題之 して, 都市計画の柱のひとつとしての造園、デザイン思 想, 社会的発言と貢献, アカデミズムについて指摘され 今後への期待を, (株) 計画技術研究所の林泰義氏は, ご経験をもとに，コミュニティと共に創造し，自然に開 かれた多義的な環境を維持・再生させることへの期待を, （財）自然環境研究センターの真板昭夫氏は，野鳥や昆 虫が生息することの出来る「生き物のための緑地」の視 点から、これからの造園のあり方について提言された。

東京大学の篠原修氏は, 造園の外構的, 修景的位置つ けの問題点, 造園の教育と研修のあり方, 造園家像の明 示とス夕ー㕕成の必要性について述べられ, アイデンティ ティ論は無用になっていくとされ，竟原敬氏は，水戸の 公園計画, サーフ’ 90 , 幕張の住宅地計画, 環境芸術の コンペのエピソードから「造園家」はランドスケープ・ アーキテクトでは無いとし，いくつかの提言をされ，建 築家の内井昭蔵氏は, ランドスケープアーキテクトは私 から公に亘る連続した庭のあり方を常に考える立場の人 とされ, その役割を新しい職能として論じられ, 東京工 業大学の中村良夫氏は, 造園の困難之希望について述へ られ，造園の自己拡散のなかで捨ててはならない遺産と して, 空間の詩人としての自覚を持つことの必要性を指 摘された。

この特集において各氏の論じられたことは，いずれも 造園家のあり方を考えるうえで極めて示唆に富むむので ある。幸い，今，造園に対する社会的ニーズ，期待が高 まっているが，このような時にこそ，自己満足に陥らな いよう努力していかなけ扎ばならない。他分野からの批 判も謙虚に受けとめ, 自らの足元を見つめ直し, よりよ い環境の創造をめざして前進して行きたいと考えるもの である。終わりに, ご多忙のところを本特集に執筆を快 諾された各位に，心から御礼を申し上げたい。 